\title{
WYMOWA POLSKA JAKO OBCA. ROZWIĄZYWANIE TRUDNOŚCI ARTYKULACYJNYCH W GRUPIE MIĘDZYNARODOWEJ NA ROCZNYM KURSIE PRZYGOTOWAWCZYM
}

\begin{abstract}
Słowa kluczowe: wymowa polska jako obca, grupa międzynarodowa, indywidualne trudności artykulacyjne, nauczanie wymowy

Streszczenie. Niniejszy tekst dotyczy pracy nad wymową polską jako obcą w grupie międzynarodowej podczas Rocznego Kursu Przygotowawczego w Szkole Języka Polskiego i Kultury dla Cudzoziemców we Wrocławiu. Porusza problem badania trudności artykulacyjnych, opisu wymowy studenta oraz doskonalenia jego sprawności w zakresie wymowy. Formułuje także ogólne wnioski dotyczące planowania zadań fonetycznych dla cudzoziemców.
\end{abstract}

\section{WSTĘP}

Niniejszy artykuł dotyczy sposobu nauczania wymowy polskiej na Rocznym Kursie Przygotowawczym (dalej jako RKP) w Szkole Języka Polskiego i Kultury dla Cudzoziemców we Wrocławiu (dalej jako SJPiK UWr). Podczas trwania RKP studenci mają zajęcia kształcące i integrujące poszczególne sprawności językowe, czyli poza ćwiczeniami m.in. z gramatyki, leksyki, słuchania i mówienia, rozumienia tekstu mówionego i czytanego, wiedzy o Polsce czy śpiewania mają również osobny lektorat $\mathrm{z}$ wymowy polskiej. Przez dwa semestry mogą doskonalić swoją artykulację raz w tygodniu przez 45 minut w trzech grupach o różnym poziomie zaawansowania (od poziomu elementarnego przez początkujący po średnio zaawansowany). Grupy są, oczywiście, zróżnicowane pod względem językowym, co egzemplifikuje poniższa tabela.

*anna.majewska-tworek@uwr.edu.pl, Uniwersytet Wrocławski, Wydział Filologiczny, Zakład Językoznawstwa Stosowanego, Pracownia Polszczyzny Mówionej, pl. Biskupa Nankiera 15b, 50-140 Wrocław. 
Tabela 1. Zróżnicowanie językowe grup na RKP w SJPiK UWr w roku akademickim 2017/2018

\begin{tabular}{|l|c|l|c|l|c|}
\hline \multicolumn{1}{|c|}{$\begin{array}{c}\text { GRUPA } \\
\text { ELEMENTARNA }\end{array}$} & $\begin{array}{c}\text { Liczba } \\
\text { osób }\end{array}$ & $\begin{array}{c}\text { GRUPA } \\
\text { POCZĄTKUJĄCA }\end{array}$ & $\begin{array}{c}\text { Liczba } \\
\text { osób }\end{array}$ & $\begin{array}{c}\text { GRUPA ŚREDNIO } \\
\text { ZAAWANSOWANA }\end{array}$ & $\begin{array}{c}\text { Liczba } \\
\text { osób }\end{array}$ \\
\hline Język chiński & 4 & $\begin{array}{l}\text { Język ukraiński, } \\
\text { rosyjski }\end{array}$ & 4 & Język chiński & 2 \\
\hline Język koreański & 1 & Język rosyjski & 2 & $\begin{array}{l}\text { Język rosyjski, } \\
\text { białoruski }\end{array}$ & 1 \\
\hline Język wietnamski & 1 & Język niemiecki & 1 & $\begin{array}{l}\text { Język ukraiński, } \\
\text { rosyjski }\end{array}$ & 1 \\
\hline Język arabski (iracki) & 1 & Język chiński & 1 & Język filipiński & 1 \\
\hline Język francuski & 1 & Język turecki & 1 & - & \\
\hline Język portugalski & 1 & - & & & - \\
\hline Język angielski (USA) & 2 & - & & & \\
\hline
\end{tabular}

Źródło: opracowanie własne

Nawet tak duże zróżnicowanie językowe studentów nie jest przeszkodą w dobrym zorganizowaniu zajęć z wymowy. Trzeba sobie bowiem uświadomić, że praca $\mathrm{w}$ każdej grupie zawsze wymaga uwzględnienia indywidualnych trudności, które występują u poszczególnych studentów, a te wynikają zarówno ze zjawisk interferencyjnych, jak i możliwości słuchowych oraz umiejętności korygowania pracy własnych narządów artykulacyjnych. Nie bez znaczenia jest tu również zaangażowanie własne uczącego się w trakcie wykonywania wszystkich zadań.

Roczną pracę nad wymową studentów można podzielić na trzy etapy, które (w zależności od tempa osiąganych efektów) czasem muszą się na siebie nakładać:

a) uczenie najtrudniejszych miejsc polskiej fonetyki: rozszerzanie zdolności słuchowych i artykulacyjnych w tym zakresie;

b) analiza sprawności artykulacyjnej każdego studenta;

c) doskonalenie wymowy, prozodii lingwistycznej i emocjonalnej (ze szczególnym uwzględnieniem stwierdzonych trudności) w zadaniach o charakterze komunikacyjnym.

Przedstawiony podział wynika z zastosowania wiedzy teoretycznej, wzbogaconej trudnym do przecenienia doświadczeniem zdobywanym podczas wieloletniej pracy we wrocławskiej SKJPiK. Poszczególne etapy zostaną pokrótce scharakteryzowane w kolejnych częściach niniejszego artykułu. 


\section{NAJTRUDNIEJSZE MIEJSCA POLSKIEJ FONETYKI A ROZWIJANIE ZDOLNOŚCI PERCEPCYJNYCH ORAZ ARTYKULACYJNYCH}

Obecnie stan badań nad trudnościami fonetycznymi studentów uczących się języka polskiego jako obcego jest znacznie bogatszy niż ponad 20 lat temu (por. m.in.: Maciołek, Tambor 2018; Biernacka 2015), gdy w SJPiK we Wrocławiu podjęto decyzję o wprowadzaniu w różnej formie i różnym wymiarze ćwiczeń z wymowy polskiej. Dzięki dostępnym wynikom badań empirycznych z zakresu fonetyki i fonologii lektor może posiąść wiedzę o głównych trudnościach cudzoziemców w omawianym zakresie już przed rozpoczęciem swoich pierwszych zajęć. Trudne miejsca wskazują także same materiały do ćwiczeń, których w ostatnim czasie przybyło (por. m.in. Kołaczek 2017). Jednak mając na co dzień kontakt z lektorami języka polskiego, przeszkolonymi i przygotowywanymi do nauczania wymowy polskiej jako obcej, nie sposób odnieść wrażenia, że korygowanie artykulacji wciąż budzi pewne obawy i jest odsuwane na dalszy plan. Wydaje się, że przyczynami tego są m.in.: własny lęk przed niepowodzeniem („,moje instrukcje mogą się okazać zupełnie nieskuteczne"), małe albo nawet żadne doświadczenie praktyczne w korygowaniu artykulacji (,chyba jednak nie umiem pomóc”), opór przed skoncentrowaniem się na pracy narządów artykulacyjnych - własnych i studenta (,wstydzę się eksponować pracę własnego aparatu artykulacyjnego”).

Każdy lektor (i ten z dużym doświadczeniem, i ten początkujący) musi sam określić trudności fonologiczne i fonetyczne, występujące w jego grupach. Cenne dane z zakresu konfrontatywnej fonetyki artykulacyjnej, biorącej na warsztat interferencyjne zjawiska wymowy polskiej jako obcej, wyznaczają praktykowi pewien punkt wyjścia, ogólną informację („wiem, czego mogę się spodziewać”). Jednak na początku semestru to lektor właśnie musi samodzielnie ocenić sprawności percepcyjne i artykulacyjne wszystkich swoich studentów. Pracuje z kilkulub kilkunastoosobową grupą, więc w miarę spójny obraz trudności uzyskuje nie po pierwszym spotkaniu, lecz co najmniej po trzech czy czterech intensywnych zajęciach.

Na RKP w SJPiK Uniwersytetu Wrocławskiego w trakcie pierwszych zajęć $\mathrm{z}$ wymowy studenci są poddawani testowi artykulacyjnemu z wykorzystaniem małego fragmentu Przesiewowego testu logopedycznego (Tarkowski 2008). Jedno zadanie z podtestu wymowy zostało rozszerzone, a przez to nieco lepiej dostosowane do sprawdzania artykulacji cudzoziemców. W próbach sylabowych jest sprawdzana artykulacja tych spółgłosek, które studentom z różnymi językami natywnymi najczęściej sprawiają trudności bardzo różnego typu. Są to następujące

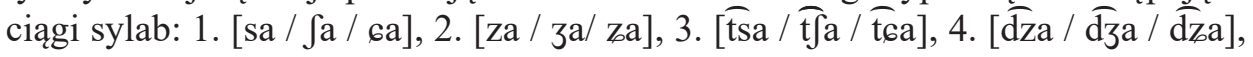
6. [ra / la / ja] oraz 6. [ba/ va / wa]. Studenci są sprawdzani przez zastosowanie 
dwóch prób: najpierw powtarzają po lektorze pojedyncze sylaby, a potem - cały szereg. W pierwszej próbie sprawdza się zdolności percepcyjne i motoryczne (w tym imitacyjne i kinestetyczne) studenta, a w drugiej - zdolność kinetyczną, czyli umiejętność szybkiego i właściwego przełączania się z jednej pozycji artykulacyjnej na drugą. W kolejnym kroku w podstawowym zakresie jest sprawdzany słuch fonologiczny (Kwiatkowska 2015, por. też m.in.: Majewska-Tworek 2010, s. 16, 22). Odrębne zadania trzeba przeprowadzić na percepcję i artykulację samogłosek ustnych o wartości fonemu we współczesnej polszczyźnie (Kołaczek 2017, s. 11-13). Już na pierwszych zajęciach o samogłoskach ustnych warto zbadać percepcję samogłosek przednich w wygłosie. Do tego celu jest wygodne ćwiczenie z przymiotnikami określającymi kolory - szczególnie w grupach elementarnych (Majewska-Tworek 2010, s. 12). Spełnione zostaje w ten sposób ważne zalecenie metodyczne Jolanty Tambor, by starać się uczyć wymowy na materiale leksykalnym znanym studentowi (por. Maciołek, Tambor 2018). Ponadto bardzo przydatne podczas zajęć przez cały rok jest wyuczenie podpowiedzi gestycznych dla samogłosek. Wspomagają one zadania i percepcyjne, i artykulacyjne. Szczególnie cenne są te, które dotyczą samogłosek przednich $[\varepsilon /$ i / i], które (jak wiadomo) są szczególnie trudne dla dużej części cudzoziemców. Rzetelne wykonanie ćwiczeń wstępnych jest bardzo pomocne przy rozwiązywaniu nawracających czy uporczywych trudności fonologiczno-fonetycznych i ortofoniczno-ortograficznych. Umożliwia dobre zorganizowanie całego kursu z zakresu wymowy (Majewska-Tworek 2017).

Tuż po wykonaniu opisanych zadań studenci uzyskują pierwsze instrukcje korygujące wymowę. Powyżej opisane zadania stanowią niejako punkt wyjścia podczas rocznych zajęć z wymowy polskiej. Po ich wykonaniu należy stale obserwować indywidualne trudności uczestników zajęć i na bieżąco stosować różne sposoby korygowania wymowy. Do najczęściej wykorzystywanych i najbardziej skutecznych należą metody modyfikacji, „,dogodnego kontekstu” i ,słów-kluczy” (por. m.in. Rodak 2009; Majewska-Tworek 2010).

\section{INDYWIDUALNA OCENA SPRAWNOŚCI ARTYKULACYJNEJ}

Test osiągnięć z wymowy przeprowadzony w sesji zimowej w roku akademickim 2018/2019 polegał na czytaniu fragmentu opisu domu (Majewska-Tworek 2010, s. 85). W zależności od indywidualnego tempa czytania otrzymano próbki mowy liczące od 1,09-2,55 min. Tekst dla wszystkich osób był ten sam. Grupa średnio zaawansowana czytała opis w całości, początkująca - jego cztery części, a elementarna - trzy części. Trzeba zaznaczyć, że była to kolejna próba kształtowania testu z wymowy. Pierwsza miała postać wypowiedzi spontanicznej 
(przygotowanie i samodzielne przedstawienie opisu zdjęcia ze słowami kluczami), druga składała się z testu fonologicznego oraz z czytania podanego tekstu dialogowego: gotowego i rozbudowanego samodzielnie przez studenta o kilka własnych kwestii. Każda z nich ma swoje ograniczenia. Tekst czytany na pewno daje porównywalne dane, łatwe w opisie oraz analizie.

Wybrane z transkryptów wyrazy fonetyczne uporządkowano ze względu na występujące $w$ nich różne typy zniekształcenia struktury fonologiczno-fonetycznej; wyróżniono substytucje, deformacje, metatezy, epentezy, elizje (Surowaniec 1992). Podczas opisu uzyskanego materiału językowego za podstawę teoretyczną przyjęto opis polskiego systemu fonologicznego za Gramatyka wspótczesnego języka polskiego (Dukiewicz, Sawicka 1995). Przedstawiony w niej inwentarz fonemów stanowił ważny punkt odniesienia zwłaszcza podczas stwierdzania substytucji i deformacji oraz starannego i konsekwentnego odróżniania tych dwóch zjawisk od siebie. Odnotowano także przykłady, w których wystąpiła większa komplikacja wymienionych powyżej zmian w strukturze fonologicznej wyrazów, próby autokorekt fonetycznych (Majewska-Tworek 2014) i inny od normatywnego przebieg procesów koartykulacyjnych. Sporządzono również syntetyczny opis prozodii czytanego tekstu. Przeprowadzona analiza miała charakter wyłącznie jakościowy.

Z powodu ograniczeń objętościowych w niniejszym tekście nie jest możliwe przedstawienie danych dotyczących wszystkich uczestników kursu. Zadecydowano więc, że zostaną zaprezentowane trudności artykulacyjne studentów chińskich i ukraińskich. Są to od kilku lat bowiem dwie najliczniejsze grupy językowe na Rocznym Kursie Przygotowawczym. Taki wybór materiału pozwolił więc na egzemplifikację różnorodnych trudności artykulacyjnych osób z tymi samymi językami natywnymi (por. tabele 2, 3).

\subsection{STUDENCI CHIŃSCY}

W semestrze zimowym na RKP we wrocławskiej SJPiK uczyło się - w trzech różnych grupach - siedmiu studentów z Chin: czworo w grupie elementarnej, jeden - w początkującej, dwoje - w średnio zaawansowanej. Sześciu z nich regularnie uczestniczyło w kursie. Natomiast jedna osoba miała bardzo dużą absencję. Czytany przez nią tekst okazał się niezrozumiały i z tego powodu nie był poddany analizie.

W grupie elementarnej wszyscy studenci (CH0_01, CH0_02, CH0_03) zmagali się z prawidłowym odtworzeniem struktury dźwiękowej wyrazu fonetycznego. Przy wciąż niskim poziomie sprawności fonetycznej nie byli w stanie zachować prawidłowego tempa i prozodii wypowiedzi. Z tabeli 2 wynika, że u stu- 
dentów można zauważyć wszystkie typy zniekształcania struktury brzmieniowej (często różne typy występują w jednym wyrazie fonetycznym). Jednak wolne tempo czytania oraz autokorekty (lub też ich próby) sprawiły, że ich teksty są zrozumiałe dla osoby słuchającej.

Tabela 2. Analiza wymowy studentów z Chin-przykłady trudności na poziomie elementarnym.

\begin{tabular}{|c|c|c|c|}
\hline Typ trudności & CH0_01 & CHO_02 & CHO_03 \\
\hline Substytucje & $\begin{array}{l}\text { 'viderets / ta(r) } \\
\varepsilon \int \text { / tirks / oblas / } \\
\text { um,ivalka / v,if,i / u(.) } \\
\text { kuxni / gutuje / stuf }\end{array}$ & 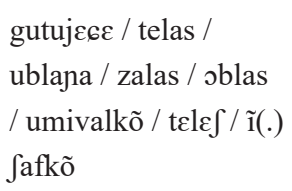 & \\
\hline Deformacje & 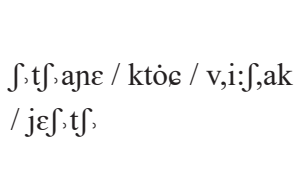 & $\operatorname{Ren}(.) \widehat{\mathrm{t}}(.) \operatorname{nik} / \mathrm{s}, \widehat{\mathrm{t}}$ a a $\varepsilon$ & $\begin{array}{l}\text { budz,ik / obỏkncj } \\
\text { / na’ubriana / obras } \\
\text { / zaras / lustrì / } \\
\text { gotuje } \int, \varepsilon\end{array}$ \\
\hline Metatezy & ub,ja(r)na & & \\
\hline Epentezy & z(i)pastõ & 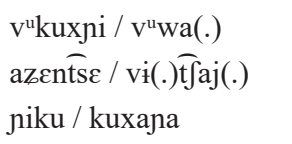 & $\mathrm{v}^{\mathrm{u}}(.) \mathrm{kuxpi} / \mathrm{kuxanja}$ \\
\hline Elizje & nakuxntse & v,ic / kosmtici & ufko \\
\hline $\begin{array}{l}\text { Złożone zjawiska } \\
\text { (np. substytucja } \\
\text { z metatezą) }\end{array}$ & $\begin{array}{l}\text { wuzok / kỏsmtci / } \\
\text { ut } \int \text { ajpiku / lusl(i) } \\
\text { tro / z(.)p(i) Jnitsem / } \\
\text { 'viderets }\end{array}$ & 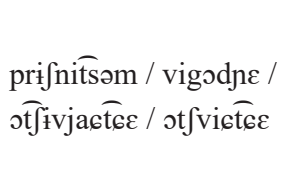 & ren’t̂nici / ktuf, / stuji \\
\hline $\begin{array}{l}\text { Nieprawidłowe } \\
\text { koartykulacje }\end{array}$ & & vidate / v,idate // & 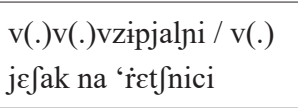 \\
\hline Autokorekty & na(.)rejk/ren/ren/t nik & 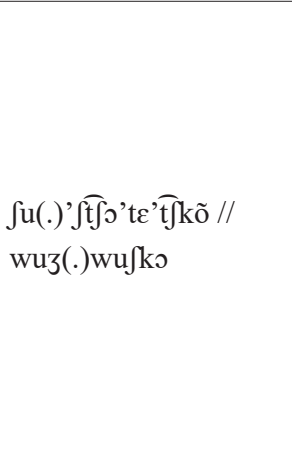 & 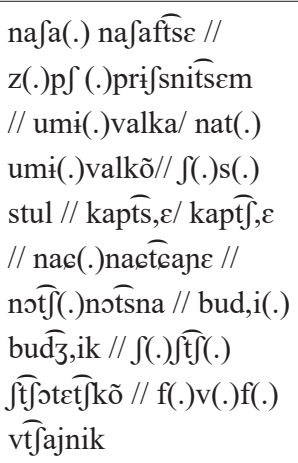 \\
\hline
\end{tabular}




\begin{tabular}{|c|c|c|c|}
\hline $\begin{array}{l}\text { Typ trudności } \\
\text { (cd.) }\end{array}$ & CH0_01 (cd.) & CH0_02 (cd.) & CH0_03 (cd.) \\
\hline $\begin{array}{l}\text { Prozodia i tempo } \\
\text { czytanego tekstu }\end{array}$ & $\begin{array}{l}\text { Intonacja monotonna. } \\
\text { Bardzo częste } \\
\text { skandowanie wyrazów } \\
\text { i sylab. Upraszczanie } \\
\text { struktury sylabowej } \\
\text { wyrazów. }\end{array}$ & $\begin{array}{l}\text { Stara się kształtować } \\
\text { intonację zdania } \\
\text { polskiego. Zwalnia } \\
\text { wymowę przy } \\
\text { wyrazach trudnych } \\
\text { fonetycznie } \\
\text { (z sukcesem } \\
\text { artykulacyjnym). } \\
\text { Skandowanie } \\
\text { sylab w obrębie } \\
\text { wyrazów, a także } \\
\text { w obrębie wyrażeń } \\
\text { przyimkowych. }\end{array}$ & $\begin{array}{l}\text { Bardzo wolne } \\
\text { tempo czytania, } \\
\text { monotonna prozodia, } \\
\text { skandowanie, duży } \\
\text { trud artykulacyjny. } \\
\text { Problemy } \\
\text { koartykulacyjne, } \\
\text { liczne autokorekty } \\
\text { (częściowo } \\
\text { prawidłowe). }\end{array}$ \\
\hline
\end{tabular}

Źródło: opracowanie własne

W grupie początkującej i średnio zaawansowanej są studenci chińscy (tab. 3), którzy uczą się w SJPiK już drugi rok. U studenta w grupie początkującej (CH1_04) w ogólnym wrażeniu słuchowym dominowała dość monotonna intonacja. Poza tym częściej niż u innych chińskich studentów z tych dwóch grup wystąpiły u niego epentezy i elizje. Natomiast studentka średnio zaawansowana (CH2_05) ma zdecydowanie dobrą artykulację. Potrafi wymówić wszystkie spółgłoski i samogłoski (choć w większości kontekstów z pewnymi tendencjami do substytucji w obrębie grup spółgłoskowych). Część wyrażeń przyimkowych została wymówiona przez nią bardzo poprawnie. Jej tempo czytania jest dość wolne, ale przez to wymowa - zdecydowanie zrozumiała. W odsłuchu bardziej raziła monotonna intonacja, przenoszenie akcentu i tendencja do skandowania w obrębie fraz występujących w granicy zdania. Na tle wszystkich studentów chińskich wyróżniła się dobrą emisją głosu. U ostatniego studenta $\mathrm{CH} 2$ _06 na plan pierwszy wysunął się problem prozodii: niewłaściwej segmentacji i intonacji tekstu mówionego. Jego intonacja nie była monotonna, wręcz przeciwnie: gdyby należało narysować jej schemat, linie intonacyjne przyjęłyby kształt sinusoidy o dużej amplitudzie i wysokiej częstotliwości. Jest to wyraźna i trudna w modyfikowaniu maniera u tego studenta. Wie, że musi się tego oduczyć, ponieważ jego sposób mówienia (i czytania) budzi uśmiech nawet wśród chińskich kolegów. 
Tabela 3. Analiza wymowy studentów z Chin-przykłady trudności na poziomie początkujacym i średnio zaawansowanym.

\begin{tabular}{|c|c|c|c|}
\hline Typ trudności & CH1_04 & CH2_05 & CH2_06 \\
\hline Substytucje & sto' $1, \mathrm{ik}^{\mathrm{y}} / \mathrm{ot} \int \mathrm{iv}, \mathrm{it}^{\circ} \cdot \varepsilon$ & 3عm,nakam,i & pufci / stuf \\
\hline Deformacje & $\begin{array}{l}\text { òvỏlne / zmózem / } \\
\text { v,èjak / stöji }\end{array}$ & bet $\int, k a / v w a z, \varepsilon n t s \varepsilon$ & 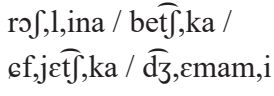 \\
\hline Epentezy & 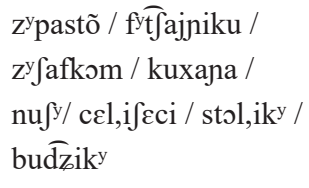 & & $z^{y}$ prifjnitsem \\
\hline Elizje & $\begin{array}{l}\operatorname{pot}(.) \mathrm{u} \int \mathrm{c} \varepsilon \mathrm{m} / \mathrm{v}, \mathrm{ic} / \\
\text { polevj / ovlne / gotvana }\end{array}$ & $\mathrm{v}, \mathrm{ic}$ & \\
\hline $\begin{array}{l}\text { Złożone } \\
\text { zjawiska } \\
\text { (np. substytucja } \\
\text { z metatezą) }\end{array}$ & 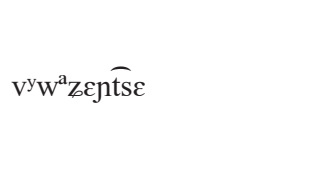 & & \\
\hline $\begin{array}{l}\text { Nieprawidłowe } \\
\text { koartykulacje }\end{array}$ & $\begin{array}{l}\operatorname{pod}(.) \text { ctcanõ / fncj / } \\
\text { umivalka }\end{array}$ & $\begin{array}{l}\mathrm{z}(.) \text { pasto / } \mathrm{z}(.) \\
\mathrm{p} \int \varepsilon \int \mathrm{klonim}, \mathrm{i} / \\
\text { a pod }^{\mathrm{y}} \mathrm{wu} \text { ccem }\end{array}$ & 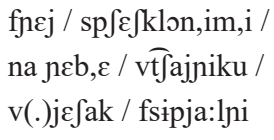 \\
\hline $\begin{array}{l}\text { Prozodia } \\
\text { i tempo } \\
\text { czytanego } \\
\text { tekstu }\end{array}$ & $\begin{array}{l}\text { Monotonna prozodia, } \\
\text { dość częste przenoszenie } \\
\text { miejsca akcentu, } \\
\text { np.: [na'rent]jnici / } \\
\text { 'zy(.)'pri']ni'tsem] }\end{array}$ & $\begin{array}{l}\text { Dość wolne tempo } \\
\text { czytania. Pojawia się } \\
\text { w niektórych miejscach } \\
\text { skandowanie i zmiana } \\
\text { miejsca akcentu. }\end{array}$ & $\begin{array}{l}\text { Problem z właściwą } \\
\text { segmentacją tekstu } \\
\text { w trakcie czytania } \\
\text { (i mówienia). Sprawia } \\
\text { to, że intonacja nie } \\
\text { jest naturalna. Raczej } \\
\text { przypomina szkolną } \\
\text { deklamację. }\end{array}$ \\
\hline
\end{tabular}

Źródło: opracowanie własne

\subsection{STUDENCI UKRAIŃSCY}

Studenci ukraińscy są drugą pod względem liczebności grupą na RKP (por. tabela 1). Wszyscy znają język rosyjski, co ma swoją genezę w dwujęzyczności najbliższej rodziny. Wspólną cechą wymowy tych studentów jest duża ilość deformacji w obrębie spółgłosek [S/ $3 / \widehat{\mathrm{t} /} / \widehat{\mathrm{d}}]$ i $[\mathrm{w} / \mathrm{1} / \mathrm{v}]$, częste substytucje w obrębie opozycji [i] - [i] (mocno funkcjonalnie obciążonej w polszczyźnie), a także 
nieprawidłowy przebieg zjawisk palatalizacyjnych (pod wpływem języka rodzimego). Zwraca również uwagę tendencja do napinania samogłosek, nadmiernej labializacji samogłoski [ొ] i wydłużania jej brzmienia (patrz: tabela 3).

Tabela 4. Analiza wymowy studentów z Ukrainy - przykłady trudności.

\begin{tabular}{|c|c|c|c|c|c|}
\hline Typ trudności & U1_01 & U1_02 & U1_03 & U1_04 & U2_01 \\
\hline Substytucje & $\begin{array}{l}\text { sklanka / } \\
\text { videlets / } \\
\text { filizanci/ }\end{array}$ & $\begin{array}{l}\text { vici/ videtets } \\
\text { / t } \int, \mathrm{i}\end{array}$ & $\begin{array}{l}\text { tf,i/ stołik / } \\
\text { videtets }\end{array}$ & 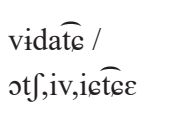 & 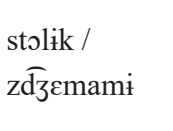 \\
\hline Deformacje & $\begin{array}{l}\text { ktos, / łufks } \\
\text { / tampka // } \\
\text { v,is,I / (v,ici) }\end{array}$ & 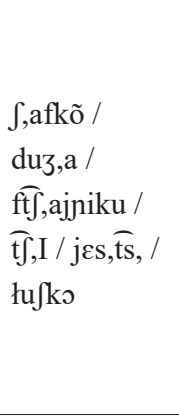 & 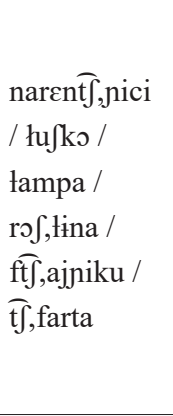 & $\begin{array}{l}\int, \widehat{\int} \int \text {,otẽt } \int, \text {,kõ } \\
\text { / tampka / } \\
\text { ț } \text {,varta }\end{array}$ & 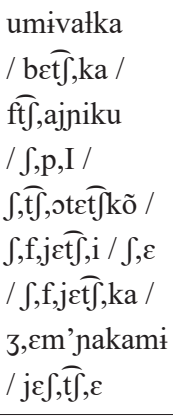 \\
\hline Epentezy & $\mathrm{z}^{\mathrm{y}}$ afkõ & $\mathrm{z}^{\mathrm{y}}$ prife,nitsem & & & \\
\hline Elizje & & & $\begin{array}{l}\text { dzzcnim / } \\
\text { vana / }\end{array}$ & & \\
\hline $\begin{array}{l}\text { Złożone } \\
\text { zjawiska } \\
\text { (np. substytucja } \\
\text { z metatezą) }\end{array}$ & & & 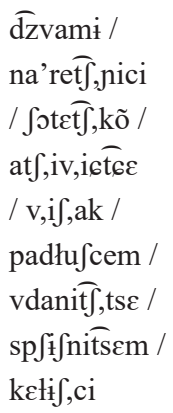 & $\begin{array}{l}\mathrm{v}(.) \widehat{\mathrm{t}} \text {,ajniku } \\
\text { / rof,lina }\end{array}$ & ava'tsovimi \\
\hline $\begin{array}{l}\text { Nieprawidłowe } \\
\text { koartykulacje }\end{array}$ & 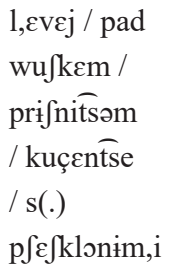 & $\begin{array}{l}\text { otfivictece / } \\
\text { fsipalni }\end{array}$ & 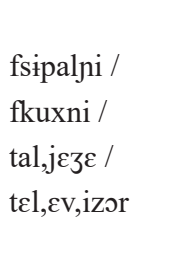 & $\begin{array}{l}\text { kuçenka / po } \\
\text { 1,evej / }\end{array}$ & $\begin{array}{l}\text { fsipjalni / } \\
\text { ko: } \int\end{array}$ \\
\hline Autokorekty & & $\begin{array}{l}\text { na'rẽt } \int,(.) / \\
\text { na'rẽt } \int \text { jici }\end{array}$ & & $\begin{array}{l}\text { na re/ } \\
\text { rẽnţ,yici }\end{array}$ & $\operatorname{pri}(.) \int j i t s \varepsilon m$ \\
\hline
\end{tabular}




\begin{tabular}{|c|c|c|c|c|c|}
\hline $\begin{array}{c}\text { Typ trudności } \\
\text { (cd.) }\end{array}$ & U1_01 (cd.) & U1_02 (cd.) & U1_03 (cd.) & U1_04 (cd.) & U2_01 (cd.) \\
\hline $\begin{array}{l}\text { Prozodia } \\
\text { i tempo } \\
\text { czytanego } \\
\text { tekstu. } \\
\text { Inne uwagi }\end{array}$ & $\begin{array}{l}\text { Staranna, wyra- } \\
\text { zista intonacja. } \\
\text { Dość wolne } \\
\text { tempo czytania. } \\
\text { Kilkakrotna } \\
\text { zmiana akcentu } \\
\text { wyrazowego } \\
\text { [ta'le / zz'gar]; } \\
\text { miejscami } \\
\text { - skłonność do } \\
\text { akania [a'valne / } \\
\text { pad'wufkem] }\end{array}$ & $\begin{array}{l}\text { Szybkie tem- } \\
\text { po czytania. } \\
\text { Studentka dba } \\
\text { o intonację } \\
\text { poszczególnych } \\
\text { zdań. }\end{array}$ & $\begin{array}{l}\text { Stara się o od- } \\
\text { powiednie zróż- } \\
\text { nicowanie linii } \\
\text { intonacyjnych. } \\
\text { Tempo czytania: } \\
\text { umiarkowane. }\end{array}$ & $\begin{array}{l}\text { U studentki } \\
\text { miejscami wy- } \\
\text { stępuje przeno- } \\
\text { szenie akcentu: } \\
{\left[\mathrm{v}, \varepsilon^{\prime} \text { 'ak / ta' } 1 \varepsilon \int /\right.} \\
\text { ze'gar]. } \\
\text { Tempo czytania } \\
\text { umiarkowane. }\end{array}$ & $\begin{array}{l}\text { Staranne kształ- } \\
\text { towanie linii } \\
\text { intonacyjnych } \\
\text { w kolejnych } \\
\text { wypowiedze- } \\
\text { niach. Spokojne } \\
\text { tempo czytania. }\end{array}$ \\
\hline
\end{tabular}

Źródło: opracowanie własne

Podczas zajęć studentka U1_01 wyróżniała się wrażliwością na staranność wymowy. Ma stosunkowo dużą świadomość fonetyczną. Bez trudu potrafiła skorzystać z instrukcji podawanych przez lektora. Instrukcje zapadały jej w pamięć, dzięki czemu stosowała je także na następnych zajęciach. Ma dobry słuch fonologiczny, fonetyczny, dobre wyczucie położenia narządów artykulacyjnych, co ułatwiało jej korygowanie wymowy. Potrafi starannie wymówić wszystkie polskie głoski, co znajduje odzwierciedlenie w jej nagranej wypowiedzi. Najtrudniejsze są dla niej natywne nawyki koartykulacyjne, które też w specjalnie przygotowanych ćwiczeniach potrafi korygować.

Studentki U1_02 i U1_04 potrafią wymówić prawidłowo polskie głoski we wszystkich kontekstach, jednak analiza obu nagranych wypowiedzi wykazała m.in. dość uporczywe zmiękczanie spółgłosek [ $/ 3 / \mathrm{t} / \mathrm{d} 3]$. Student U1_03 poza odnotowanymi w tabeli cechami wymowy szczególnie mocno napinał i przeciągał samogłoski, upraszczał niektóre grupy spółgłoskowe. W trakcie kursu miał

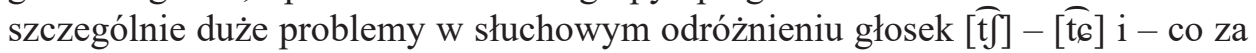
tym idzie - poprawną wymowę tych głosek w izolacji. Z trudem korygował swoją wymowę w tym zakresie. Wymagał nieco zindywidualizowanego treningu (m.in. bardzo pomogła mu uproszczona instrukcja: $[\widehat{\mathrm{t}}] \rightarrow[\mathrm{t}+\mathrm{f}]$, ćwiczenie uzyskanej głoski w sylabie z samogłoską [i], ćwiczenie słuchowe i artykulacyjne par typu: $\left[\mathrm{fi}^{\mathrm{i}}\right]-[\mathrm{t} \mathrm{j} \mathrm{i}]-[\widehat{\mathrm{t}} \mathrm{i}]$, trening z wyrazami-kluczami, np., czy, czyta, czysty). W grupie średnio zaawansowanej studentka U2_01 wykazała cechy wymowy podobne do studenta U1_03. Jednak wyróżniała się lepszym słuchem językowym oraz większą sprawnością w zakresie korygowania swojej wymowy w trakcie ćwiczeń pod kierunkiem lektora (przy jego stosunkowo małym wysiłku). Oznacza to zdolność do wysokiej autokontroli własnej wymowy. 


\section{JAK KONTYNUOWAĆ DOSKONALENIE WYMOWY POLSKIEJ JAKO OBCEJ NA RKP?}

Dobrze jest zaprezentować wszystkie umiejętności studentów przed lektorami nauczającymi gramatyki, leksyki czy innych sprawności, by ci znali możliwości poszczególnych osób z grup. Na co dzień bowiem (podczas innych zajęć) wszyscy koncentrują się na wybranych zagadnieniach, zapominając o wymowie. $\mathrm{Z}$ całą pewnością potrzebny jest duży nacisk na codzienne integrowanie sprawności w tym zakresie. Jest to bardzo trudne, co wykazały nie tylko nagrane wypowiedzi, ale także choćby proste polecenia na lektoracie, np. prośba po dobrze wykonanym zadaniu artykulacyjnym: ,a teraz proszę sobie wyobrazić, że jest pan dziennikarzem radiowym i to samo czyta pan do mikrofonu podczas audycji dla dzieci". Przy próbie wejścia w rolę i próbie modelowania intonacji poprawność artykulacyjna zdecydowanie zeszła na drugi plan. Okazuje się, że w takich sytuacjach bardzo dobrze oddziałuje na studentów obecność hospitujących osób, które nie tylko obserwują przebieg zajęć, ale też pełnią rolę wspomagającą podczas pracy w podgrupach. Praca na tak zorganizowanych zajęciach zawsze staje się intensywniejsza i bardziej efektywna.

Ponadto należy stale wzbogacać istniejące już pomoce do nauczania wymowy o kolejne ćwiczenia, które będą choć w drobnym stopniu i fragmentarycznie zintegrowane z nauczaniem gramatyki, leksyki, pisaniem, doskonaleniem zdolności konwersacyjnych czy rozwijaniem wiedzy o Polsce. W porównaniu do istniejącej już oferty podręczników tych do doskonalenia wymowy polskiej jako obcej wciąż jest niewiele. Wszystkie należy tak planować, by rozwijały sprawność fonetyczno-fonologiczną w szeroko rozumianym kontekście komunikacyjnym. Najogólniej w tym miejscu rzecz ujmując, należy to rozumieć jako uczenie wymowy na wyrazach, zdaniach, tekstach, które studenci będą mogli wykorzystywać na co dzień. Poza tym na zajęciach z wymowy studenci mogą, a nawet powinni (niejako przy okazji) rozwijać swoją wiedzę z zakresu słownictwa, gramatyki, ortografii. Mogą to być też zajęcia zanurzone w kontekst kulturowy, uczący czegoś o Polsce. Szczególnie inspirująca dla autorów nowych ćwiczeń jest wskazówka, by dotyczyły one jednego, wybranego pola leksykalnego; np. nazw roślin, zwierząt czy - jak wymyśliła to studentka $X$ rocznika podyplomowego studium nauczania języka polskiego jako obcego we Wrocławiu - polskich parków narodowych. Wytypowanych kilka (kilkanaście) wyrazów można wykorzystać do różnorodnych, sprawdzonych już rodzajów ćwiczeń kształcących zdolności fonetyczno-fonologiczne, ortofoniczno-ortograficzne oraz prozodię wypowiedzi. 


\section{PODSUMOWANIE}

Interesujące jest, jak się wydaje, że poza wspólnymi cechami stwierdza się pewne różnice w procesie akwizycji polskiego systemu dźwiękowego u osób z tymi samymi językami natywnymi. Jak wspomniano powyżej wynika to z indywidualnych zdolności słuchowych i motorycznych uczących się osób. Podczas pracy nad artykulacją w każdej grupie zatem jest potrzebna zarówno wyraźna indywidualizacja oddziaływania, jak i integrowanie nauczania wymowy z innymi sprawnościami językowymi.

\section{BIBLIOGRAFIA}

Biernacka M., 2015, Trudności w nauczaniu wymowy polskiej cudzoziemców w świetle wyników badań ankietowych, „Acta Universitatis Lodziensis. Kształcenie Polonistyczne Cudzoziemców”, t. 22, G. Zarzycka (red.), s. 251-265.

Dukiewicz L, Sawicka I., 1995, Gramatyka współczesnego języka polskiego. Fonetyka i fonologia, Kraków.

Ikeda A., 2008, Nie lubię igreka, czyli o trudnych głoskach w języku polskim, Tokio.

Kołaczek E., 2017, Testuj swój polski. Fonetyka, Kraków.

Kwiatkowska K., 2015, Testowanie stuchowego różnicowania polskich dźwięków mowy w nauczaniu języka polskiego jako obcego, w: E. Kubicka, A. Walkiewicz (red.), Nowe perspektywy w nauczaniu języka polskiego jako obcego III, Toruń, s. 304-316.

Maciołek M., Tambor J., 2018, Głoski polskie. Przewodnik fonetyczny dla cudzoziemców i nauczycieli uczacych języka polskiego jako obcego, Katowice.

Majewska-Tworek A., 2010, Szura, szumi i szeleści. Ćwiczenia fonetyczne nie tylko dla cudzoziemców, Wrocław.

Majewska-Tworek A., 2014, Nieptynność wypowiedzi w oficjalnej odmianie polszczyzny. Propozycja typologii, Wrocław.

Majewska-Tworek A., 2017, Od czego zaczać doskonalenie wymowy na rocznym kursie przygotowujacym do studiów w języku polskim? Na przykładzie pracy w ośrodku wrocławskim, „Kwartalnik Polonicum" nr 25, s. 17-22.

Rodak H., 2009, Terapia dziecka z wada wymowy, Warszawa.

Surowaniec J., 1992, Stownik terminów logopedycznych, Kraków.

Tarkowski Z., 2008, Przesiewowy test logopedyczny, Lublin.

Anna Majewska-Tworek

\section{POLISH PRONUNCIATION FOR NON-POLISH SPEAKERS HANDLING ARTICULATION DIFFICULTIES IN AN INTERNATIONAL GROUP DURING THE ONE YEAR PREPARATORY COURSE}

Keywords: Polish pronunciation as foreign pronunciation, international group, individual articulation difficulties, teaching pronunciation

Abstract. The article discusses the problem of Polish pronunciation for non-Polish speakers in an international group. The author describes the method of testing articulation skills of the students and presents an analysis of the main phonetic challenges. She concludes with some guidelines of how to organize the course of Polish pronunciation during the One Year Preparatory Course at the School of Polish Language and Culture for Foreigners in Wrocław. 